Biol. Neonate 1973;22:I-IV

\title{
Contents, Vol. 22, 1973
}

\section{Contents}

Satomi, S. and Matsuda, I.: Microsomal Desaturation of Linolenic into $\gamma$-Linolenic Acid in Livers of Fetal, Suckling and Pregnant Rats 1

Hahn, P. and Skala, J.: Carnitine Transferases in Human Feial Tissues 9

Sturman, J. A.; Niemann, W. H., and Gaull, G. E.: Metabolism of 35S-Methionine and 35S-Cystme in the Pregnant Rhesus Monkey 16

Dlouha, H.; Erdösova, R.; Kraus, M., and Skopkova, J.: The Effect of Sodium Intake on Maternal Milk Electrolytes and Aldosterone, Corticosterone and 18-Hydroxydeoxycorticosterone Production in the Offspring of Rats ... 38

Paton, J. B.; Fisher, D. E.; Peterson, E. N.; deLannoy, C. W., and Behrman, R.

E.: Cardiac Output and Organ Blood Flows in the Baboon Fetus $\quad 50$

Rakusan, K. and Marcinek, H.: Postnatal Development of the Cardiac Output

Distribution in Rat 58

Davis, R. M.; Baetz, A. L.; Hubbert, W. T., and Graham, C. K.: Age-Related

Change of LDH Activity and Isoenzyme Patterns in the Bovine Fetus ... 64

Sabata, V.; Znamenacek, K.; Pribylová, H., and Melichar, V.: The Effect of Glu cose in the Prenatal Treatment of Small-for-Date Fetuses 78

Watanabe, K.; Iwase, K., and Hara, K.: Heart Rate Variability during Sleep and

Wakefulness in Low-Birthweight Infants

87

Alexander, D. P.; Britton, H. G.; Cohen, N. M.; Nixon, D.A., and Parker, R.A.:

Insulin Secretion in the Fetal and Neonatal Sheep 99

Schettini, F. and Mautone, A.: Lysis of Neonatal Human Erythrocytes in Hypo-

tonic Solutions of Glucose 119

Enhörning, G.; Grossmann, G., and Robertson, B.: Pharyngeal Deposition of

Surfactant in the Premature Rabbit Fetus 126

Warshaw, J. B. and Kimura, R. E.: Changes in Hepatic Microsomal Fatty Acid

Synthesis during Development of the Rat 133

Manzke, H. and Dörner, K.: Bohr Effect, 2,3-DPG and ATP Concentrations in the

Blood of Premature Infants with RDS

Fiser, R. H.; Shultz, T. D.; Rindsig, R. B., and Beisel, W. R.: Alterations in

Plasma and Brain Lipid Metabolism during Endotoxemia in the Neonatal

Rat 155

Wu, B.; Kikkawa, Y.; Orzalesi, M. M.; Motoyama, E. K.; Kaibara, M.; Zigas,

C. J., and Cook, C. D.: The Effect of Thyroxine on the Maturation of

Fetal Rabbit Lungs 161

Turner, R. C; Oakley, N. W., and Beard, R. W.: Human Fetal Plasma Growth Hormone Prior to the Onset of Labour. Effects of Stress, Glucose, Arginine and Maternal Diabetes 
Vapaavouri, E. K.; Shinebourne, E. A.; Williams, R. L.; Heymann, M. A., and

Rudolph, A.M.: Development of Cardiovascular Responses to Auto-

nomic Blockade in Intact Fetal and Neonatal Lambs

177

Contents

III

Blackmore, D.: Duration of the Effect of Starving Neonatal Rats on the Magnitude

of the Increase in V $\theta 2$ when Exposed to Cold, on Critical Temperature,

and on Weight Gain 189

Isselhard, W.; Fischer, J. H.; Kapune,H., and Stock, W.: Metabolic Patterns of

Several Tissues of Rabbits and Guinea Pigs during Postnatal Develop

ment 201

Solomon, S. and Bengele, H. H.: Growth Rates and Organ Weights of Rats

Holtzman, D. and Moore, C. L.: Oxidative Phosphorylation in Immature Rat Brain

Mitochondria i...... 230

Albrytton, W. L.; Koops, B. L.; Hurwitz, R. E., and Kretchmer, N.: Regulation

of Pancreatic $\alpha$-Amylase in the Neonatal Mouse 243

Myers, R. E.; Valerio, Marion G.; Martin, D. P., and Nelson, Karin B.:

Perinatal Brain Damage: Porencephaly in a Cynomolgous Monkey 253

Panizon, F.; Rottini, G. D., and Tamaro, P.: Au-Anti-Au Immunocomplexes in

Neonatal Au-Associated Hepatitis 274

Corberand, J.; Pris, J., and Régnier, C.: Cytochemical Leukocyte Reactions in

Normal Newborn Infants 280

Cao, A.; Coppa, G.; Marcucci, F.; De Virgiliis, S., and Giannone, E.: Character

ization of Newborn Leukocyte Alkaline Phosphatase 286

Lauweryns, J.; Bernat, R.; Lerut, A., and Detournay, G.: Intrauterine Pneumo

nia. An Experimental Study 301

Kucera, J. and Dolezalová, Vëra : Prenatal Development of Malformed Fetuses at 28-42 Weeks

of Gestational Age (Anencephalus, Hydrocephalus, Down's Syndrome, Cleft Lip and Palate, and

Hypospadias). II. Length Gains .... 319

Roloff, D. W.; Outerbridge, E. W., and Stern, L.: Combined Positive and

Negative Pressure Ventilation in the Management of Severe Respiratory

Distress Syndrome in Newborn Infants 325

Dvorak, M.: Development of the Adrenal Gland in Pigs during the Perinatal

Period. Growth Rate and Ascorbic Acid Content of the Adrenal 338

Nicolopoulos, D.; Hadjigeorgiou, E.; Kaslaris, E., and Moschos, A.: The Size of

the Langerhans' Islets in Infants with Severe Jaundice of Varying Etiology 348

Gumbinas, Maria; Oda, Marjorie, and Huttenlocher, P.: The Effects of Corti-

costeroids on Myelination of the Developing Rat Brain 355

Winsnes, A. and Bratlid, D.: Effects of Bilirubin Loading of Pregnant Rats on

Hepatic UDP-Glucuronyltransferase Activity in the Offspring 367

Stave, U. and Armstrong, M. D.: Tissue Free Amino Acid Concentrations in

Perinatal Rabbits $\quad 374$

De Souza, S. W. and Dobbing, J.: Cerebral Oedema in Developing Brain. III. Brain

Water and Electrolytes in Immature Asphyxiated Rats Treated with

Dexamethasone $\quad 388$

Karp, W.; Sprecher, H., and Robertson, A.: Human Placental Phospholipid 
Synthesis $\quad 398$

Arcilla, Minerva B. and Sturgeon, P.: Perinatal Expression of the Lewis and Secretor Blood Group Systems 407

Larroche, J. C. and Amakawa, H.: Glia of Myelination and Fat Deposit during Early Myelogenesis 421

IV

Contents

Mims, LeRoy C. and Kotas, Robert V.: Glycerol as a Phosphatidyl Choline Pre

cursor in the Developing Mammalian Lung 436

Van Wynsberghe, D. M. and Klitgaard, H. M.: The Effects of Thyroxine and

Triiodothyroacetic Acid on Neonatal Development in the Rat

444

Novak, M.; Penn, D., and Monkus, E.: Regulation of Lipolysis in Human Neo

natal Adipose Tissue. Effects of Alteration in Carbohydrate Metabolism . 451

Author Index $\quad 468$

Subject Index $\quad 470$

S. Karger · Basel · München $\mathbf{~ P a r i s ~ · ~ L o n d o n ~ · ~ N e w ~ Y o r k ~ · ~ S y d n e y ~ A r n o l d - B o ̈ c k l i n - S t r a s s e ~ 2 5 , ~}$ CH-4011 Basel (Switzerland)

All rights, included that of translation into other languages, reserved.

Photomechanic reproduction (photocopy, microcopy) of this volume or parts thereof without special permission of the publishers is prohibited.

(C) Copyright 1973 by S. Karger AG, Verlag für Medizin und Naturwissenschaften, Basel Printed in Switzerland by Buchdruckerei Fritz Pochon-Jent AG, Bern 